\title{
Miten Monosta tuli mono ja muita merkillisiä tarinoita
}

Timo Leppänen: Merkilliset nimet. Tarinoita yritysten ja tuotteiden nimistä. Suomalaisen Kirjal-lisuuden Seura, Helsinki 2016. 432 s.

Marraskuussa 1932 Lahden Saapas- ja Lapikasteollisuus Oy:n perustaja ja johtaja Jussi Mononen päätti yhdessä muun arviointiraadin kanssa valita kenkätehtaan tuotteiden nimestä järjestetyn kilpailun voittajaksi ehdotuksen Mono. Nimen keksijä Arkki Laine kertoi johtaneensa nimen kreikan sanasta monos 'yksi, ainoa' ja sisällyttäneensä siihen näin ajatuksen tuotteen yksinäisestä asemasta markkinoilla. Samalla nimi viittasi tietysti tehtaan perustajan sukunimeen. Nimi rekisteröitiin tavaramerkiksi, mutta ilmeisesti suomalaiset kaipasivat kieleen myös yleisesti hiihtojalkinetta kuvaavaa ilmausta, koska nimi vakiintui pian yleiskielen sanaksi.

Tällä tarinalla alkaa mainonnan alan ammattilaisen, taiteen maisteri Timo Leppäsen kirjoittama teos suomalaisille tutuista yritysten ja tuotteiden nimistä. Kirjassa otsikkotasolle ikään 
kuin hakusanoiksi nostetaan lähes parisataa nimeä, ja lisäksi tekstissä putkahtelee esiin useita muitakin nimiä. Leppänen on tehnyt suuren työn kerätessään nimiin liittyvää taustatietoa sadoista lähteistä ja kymmenistä haastatteluista. Kaupallisiin nimiin liittyvää tutkimustietoa ei teoksessa ole kuitenkaan hyödynnetty, vaan teoksen tavoite on ainoastaan tarinallinen: saatesanoissaan Leppänen toteaa, että kirja on tarkoitettu niille, jotka ovat kiinnostuneita yritysten historiasta ja siitä, mitä tunnettujen nimien taustalla on.

Teoksessa esiteltävät nimet on pyritty jaottelemaan toimialan mukaan, joskaan kaikin osin jaottelu ei oikein toimi. Miksi esimerkiksi sellaiset vaatemerkit kuin Beaver's ja Rukka on sijoitettu eri jaksoon kuin Marimekko ja Nanso? Miksi lelujen ja huonekalujen nimet käsitellään yhdessä? Miksi Leiras esitellään elintarvikenimien yhteydessä ja Orion kauneudenhoitoon liittyvänä eikä lääkkeitä ole käsitelty omana alanaan ollenkaan? Moni yritys on aloittanut jollain toimialalla, mutta tullut myöhemmin tunnetuksi toisella. Näin esimerkiksi työkoneisiin ainakin omassa mielessäni ensimmäiseksi yhdistyvän Catepillar-tuotenimen esittely Työkengistä trendivaatteisiin -otsikon alla herättää ihmetystä, kunnes kertomuksen lopussa selviää, että nykyään maailmalla myydään Catepillar- ja CAT-merkillä muun muassa kenkiä, farkkuja ja reppuja.

Kirjan rakenne on muutenkin epätasapainoinen. Toimialan mukaiset osat ovat hyvin eri laajuisia. Esimerkiksi Menopelit-otsikon alla on tarinoita vain kahdeksan sivun verran, kun taas Connecting People -osassa on 30 sivua tietoa matkapuhelimista ja puhelinliittymistä ja heti perään Tietotekniikan maailma -otsikolla 40 sivua tietotekniikkaa - ja jälleen myös puhelinliittymiä ja niitä markkinoivia yrityksiä. Samoin yksittäiset tarinat ovat häiritsevässä määrin eri mittaisia. Kieltämättä Postin ja Itellan taikka Nokian vaiheissa on sivukaupalla kerrottavaa, mutta kontrasti on kovin suuri sellaisiin nimiin kuin Ikea, Lego tai Esso, joista kustakin asiaa on riittänyt vain kolmen tekstirivin verran. Toisissa tarinoissa kerrotaan yritysten vaiheista, erilaisista nimikiistoista tai nimien keksimisprosessista, kun taas toisissa kuvataan vain, mistä sanoista nimi tulee.

Leppänen ei selitä, millä perusteilla hän on valinnut juuri ne nimet, jotka hän teoksessa esittelee. Kirjassa tarinoidaan niin suomalaisten kuin myös ulkomaisten yritysten ja tuotteiden nimistä. Useimmat nimet ovat toki laajalti tunnettuja, mutta moni vähintään yhtä tunnettu nimi on jäänyt poiskin. Vahva vaikutelma syntyy, ettei nimien valinnassa ole noudatettu mitään johdonmukaista periaatetta, vaan mukaan ovat päässeet kirjoittajaa itseään kiinnostaneet nimet, joista hän on löytänyt jotain tietoa. Esimerkiksi automerkeistä esitellään Mercedes-Benz ja Audi, mutta ei Volvoa ja Saabia. Leluista nostetaan esiin Brio, Lego ja Frisbee, mutta ei esimerkiksi kotimaista Jukkaa. Yllättäen mediabrändien (MTV:n, Alma Median ja Apu-lehden) rinnalla samassa osiossa esitellään bändinnimet $A b b a$ ja Hassisen kone, joiden löyhä kytkös samannäköisiin yritysnimiin toki kirjassa ilmenee: Leppäsen mukaan Abba-yhtyeen nimi otettiin Ruotsissa aluksi huvittuneesti vastaan, kun olemassa oli jo tunnettu samanniminen kalasäilykkeiden valmistaja, ja jälkimmäisen yhteydessä Leppänen mainitsee Hassisen Kone -ompelukoneliikkeen olleen yhtyeen nimen innoittajana.

Sittemmin yleisnimiksi vakiintuneet mono ja kännykkä luotiin alun perin tuotenimiksi, mutta lukijaa saattaa ihmetyttää, miksi joukkoon on kelpuutettu myös pakaste, joka - vaikka olikin Pauligin vuonna 1946 julistaman kilpailun voittaja - alun perinkin luotiin yleisesti syväjäädytettyihin tuotteisiin viittaavaksi yleisnimeksi.

Esipuheessaan Leppänen toteaa virheellisesti, että kaupallisia nimiä on tutkittu hämmästyttävän vähän. Kaupallisten nimien tutkimusta on kuitenkin niin Suomessa kuin maailmallakin harjoitettu 1990-luvulta lähtien yhä enenevässä määrin, ja tietoa on jo varsin runsaasti saatavilla. Tällaisia lähteitä ei tässä teoksessa ole käytetty, mutta toisaalta en pidä sitä teoksen luonteen 
takia tarpeellisenakaan. Leppänen kirjoittaa elävästi, ja nimiin liittyviä, usein varsin kiehtovia tarinoita on hauska lukea, kunhan kirjaa lähestyy sekalaisena kokoelmana kertomuksia, joille on yhteistä vain kytkös kaupallisiin nimiin.

Kustantaja Suomalaisen Kirjallisuuden Seura olisi kuitenkin voinut ohjata lopputulosta tasapainoisemmaksi ja loogisemmaksi. Kirja olisi kaivannut tiukemmin rajattua teemaa. Teoksesta jää nyt kovin luonnosmainen tunne, ja se vaikuttaa enemmän kerätyltä ja hyvin esitellyltä aineistolta kuin loppuun asti hiotulta tietokirjalta. Tarinoiden pohjalta kirjoittaja olisi voinut pohtia monenlaisia asiakokonaisuuksia, kuten vaikkapa sitä, miten tuotenimestä tulee yrityksen nimi ja päinvastoin, millaisia ovat kaupallisiin nimiin liittyvät nimikiistat, miten antiikki on innoittanut nimeäjiä tai millaista tuotenimipolitiikkaa suuret yritykset ovat harjoittaneet, ja valita niistä jonkin teoksen kantavaksi teemaksi. Nyt kirja loppuu viimeiseen esiteltyyn nimeen (Loparex), eikä sen jälkeen ole edes lyhyttä yhteenvetoa. Myös kattava aakkosellinen nimihakemisto olisi palvellut lukijaa.

Timo Leppäsen kokoamat tarinat kaupallisten nimien takaa ovat mielenkiintoisia, ja ne tarjoavat runsaasti tutkimukseenkin soveltuvaa materiaalia. Kirjan aineistoa voisikin joku nimistöaiheisen pro gradun tekijä hyvin käyttää tutkimuksensa lähtökohtana - toki tietysti jonkin järkevän periaatteen mukaan poimittuna ja muulla sopivalla aineistolla täydennettynä.

Paula SJÖBlom

papisjo@utu.fi

Suomen kieli ja suomalais-ugrilainen kielentutkimus 20014 Turun yliopisto 